\title{
Effect of breast-conserving surgery and modified radical mastectomy on quality of life of early breast cancer patients
}

\author{
Heng LIU ${ }^{1}$, Chengyu LUO ${ }^{1 *}$
}

\begin{abstract}
We aimed to explore the clinical efficacy of breast-conserving surgery and modified radical mastectomy on the quality of life (QoL) in patients with early breast cancer. A total of 100 patients treated with breast-conserving surgery (BCS) were recruited in the BCS group, and 100 patients treated with modified radical mastectomy (MRM) in the MRM group. Our results showed that patients had significantly shorter operation time and hospital stay, smaller incisions, and less intraoperative blood loss in the BCS group than in the MRM group. The total complication rate was significantly lower in the BCS. The rate of good-toexcellent aesthetic outcomes in the BCS group was significantly. At one year and three years after surgery, the QoL in the BCS group was significantly higher than that in the MRM group $(\mathrm{P}<0.0001)$. In conclusion, BCS is as effective as MRM in early breast cancer, but confers better perioperative and aesthetic outcomes, higher QoL, and lower postoperative complication rate.
\end{abstract}

Keywords: breast cancer; breast-conserving surgery; modified radical mastectomy; quality of life.

Practical Application: For patients with early breast cancer, breast-conserving surgery has better perioperative and aesthetic outcomes, higher quality of life, and lower postoperative complication rate.

\section{Introduction}

Breast cancer $(\mathrm{BC})$ is the most common malignancy and one of the leading causes of cancer death among women worldwide (Mavaddat et al., 2019). Potential risk factors for BC include high body mass index, older age, family history, long menstrual periods, use of oral contraceptives, and exposure to radiation (Lee et al., 2019; Morra et al., 2019; Ein Ali Afjeh et al., 2020; Hossen et al., 2021). The vast majority of breast tumors are originated from glandular epithelial cells. Furthermore, invasive ductal carcinoma is the most common type of BC (approximately $70 \%$ ), followed by lobular, medullary, mucinous, comedo, papillary, tubular, and inflammatory carcinomas (DeSantis et al., 2017; von Minckwitz et al., 2017). The incidence of breast cancer in China accounts for about $10 \%$ of all female malignant tumors (Deng et al., 2019). With the development of imaging diagnosis, puncture technology and women's health awareness, the early detection rate of $\mathrm{BC}$ has been greatly improved (Cardoso et al., 2019; Thakur et al., 2019).

Early diagnosis and thorough treatment of $\mathrm{BC}$ are important for good prognosis. For patients with early BC, surgery is the primary choice of treatment, and modified radical mastectomy (MRM) is one of the most commonly performed surgeries. However, breast aesthetics are severely affected though MRM preserves the pectoralis major and minor muscles (Sajikumar et al., 2019). Breasts are an important secondary sexual characteristic of women whose quality of life (QoL) is seriously impaired after mastectomy. With the development of breast surgery, breast-conserving surgery (BCS) has become a new therapeutic option for patients with early $\mathrm{BC}$, which preserves the breast and ensures effective resection of the lesion, thus meeting the needs of patients (Benjamin et al., 2019). In addition, the traditional biomedical model focused on the biochemical factors leading to the onset of disease, while ignoring the social and psychological factors. As the medical model develops, the traditional model was increasingly criticized (Farre \& Rapley, 2017). Engel, a professor of psychiatry and internal medicine at the University of Rochester (New York, USA), proposed a new bio-psycho-social model to replace the biomedical model in 1977 (Grotkamp et al., 2020). After entering the 21st century, the bio-psycho-social model has been generally acknowledged. MRM was derived from radical mastectomy which was still accepted by patients with stage I or II BC until the mid-1980s (Bland et al., 2018). BCS was created later, known as more consistent with the new bio-psycho-social model since its inception, in which only the tumors and normal tissue around the tumors are removed other than the entire breast to preserve the shape and appearance of the treated breasts (Moyer, 1997). To reduce postoperative recurrence effectively, axillary lymph node dissection (LND) through separate incision, radiotherapy, chemotherapy and endocrine therapy were performed (Balthazar et al., 2021). Besides, regional differences were found in the selection of MRM and BCS, due to the higher recurrence in BCS at the early stage (Fan et al., 2017). However, the progress of radiotherapy, chemotherapy and endocrine therapy ensures a reduction of postoperative recurrence rate in patients with early BC (Strnad et al., 2016). According to bio-psycho-social medical model, it is necessary 
to pay attention not only to the clinical efficacy, but also to the social and psychological dimensions.

Nevertheless, some BC patients still have low acceptance of BCS in traditional oriental countries such as India and China (Zhang et al., 2012; Deepa et al., 2020). Therefore, we focused on the comparison of the prognosis and postoperative QoL between the two surgeries, hoping to provide strong evidence to promote the BCS in China.

\section{Materials and methods}

\subsection{General data}

A total of 200 patients with early BC who received surgical treatment in our Hospital from January 2015 to January 2017 were enrolled. The included patients were diagnosed with a single mammary tumor through Molybdenum target mammographic examination and pathological biopsy with a tumor diameter of $\leq 3 \mathrm{~cm}$ and the tumor-areola distance of $\geq 3 \mathrm{~cm}$. Patients with distant metastasis, severe hematological and immune diseases, or other malignant tumors were excluded. Patients who didn't undergo designated treatment and those with incomplete follow-up due to diseases like mental illness were also excluded.

\subsection{Methods}

\section{Breast-conserving surgery}

As to incision design, BCS was performed with two separate incisions for the breast and axilla. For patients with a lesion in the axillary tail of Spence, the most appropriate incision should be selected according to its specific location. Patients with a lesion in the upper hemisphere of the breast underwent an arcuate incision that was parallel to the areola, while patients with a lesion in the lower hemisphere of the breast were offered a radial incision through the center of the nipple. The axillary incision should be parallel along the axillary fold and the incision length of generally about $6 \mathrm{~cm}$ was modulated to make it more convenient for axillary LND.

As to lesion resection, the extended local resection or quadrantectomy was selected to remove the complete lesion, according to the actual situation. A $1-2 \mathrm{~cm}$ margin of normal tissue was removed with the lesion as well as the puncture tract. If the lesion invaded Cooper's ligament or skin, shown as invasion phenomena such as depression, it was necessary to completely remove the epidermis, otherwise the epidermis could be preserved appropriately.

As to pathological examination, peripheral margins of the resected specimens were marked and sent for frozen section examination. Patients with positive surgical margins underwent extended resection and an additional resection margin of $5 \mathrm{~cm}$ was recommended. Then pathological examination was performed again. If the results remained positive after extended resection, BCS would be replaced by MRM.

As to LND, the dissection involved lymph nodes from the leading edge of the latissimus dorsi to the deep surface of the pectoralis minor, as well as those below the axillary vein. A drain was placed in both the axilla and the incision, and the operation was completed via routine layer-by-layer suture.

\section{Modified radical mastectomy}

A fusiform incision was made around the lesion and carried to the superficial fascia, followed by free flap dissection and breast resection. A subcutaneous flap lying from the lower edge of the clavicle to the upper edge of the rectus abdominis, and from the lateral edge of the sternum to the leading edge of the latissimus dorsi was dissected. Subsequently, pectoralis major and pectoralis minor muscles were identified carefully, and the excision of flap with a breadth of $3 \mathrm{~cm}$ around the perimeter of the lesion was conducted. A drainage tube was indwelled after ipsilateral axillary lymph node dissection, and the operation was completed via routine layer-by-layer suture.

\section{Postoperative treatment}

All patients received postoperative "conformal radiotherapy+ chemotherapy+ endocrine therapy". According to actual situation, the specific treatment regimen was selected from the 2017 St. Gallen Breast Cancer Consensus (Si et al., 2020). The patients received neoadjuvant chemotherapy with taxotere, epirubicin and cyclophosphamide after surgery to consolidate treatment. One month postoperatively, those received breast conformal radiotherapy at a dose of 45-50 Gy to the whole breast plus $10 \mathrm{~Gy}$ to the tumor bed. In terms of endocrine therapy, premenopausal patients with estrogen receptor (ER) and progesterone receptor (PR) positive orally administered tamoxifen twice a day for 5 years, and postmenopausal patients with ER and PR positive orally administered letrozole once daily at a dose of $2.5 \mathrm{mg}$ for 5 years. Moreover, patients with human epidermal growth factor receptor-2 (HER-2) (+++) were given Herceptin (starting with an initial dose of $8 \mathrm{mg} / \mathrm{kg}$ intravenously for about 90 minutes, then reducing to $6 \mathrm{mg} / \mathrm{kg}$ per week for consecutive 12 months).

\subsection{Outcome measures}

Perioperative outcome measures: Operation time, incision length, intraoperative blood loss and hospital stay were observed and analyzed (Fulton et al., 2019).

Postoperative complication rates: Incidence rates of subcutaneous effusion, subcutaneous hemorrhage, flap necrosis, infection, and upper limb edema as well as the total incidence were observed and analyzed (Clough et al., 2018).

Postoperative aesthetic outcomes: One year postoperatively, the breast aesthetics were evaluated using Harris's 4-staged subjective evaluation method (van Bommel \& van Dalen, 2019). Aesthetic outcomes were classified as: having symmetrical breasts of similar shape and texture, and normal color with nipple height difference of $\leq 2 \mathrm{~cm}$ (excellent); having symmetrical breasts of similar shape and texture, and normal color with nipple height difference between $2-3 \mathrm{~cm}$ (good); having symmetrical breasts of slightly worse texture and light color with nipple height difference between $2-3 \mathrm{~cm}$ (fair); having non-asymmetric breasts of reduced size, markedly worse texture and significantly light color with nipple height difference of $>3 \mathrm{~cm}$ (poor). The rate of 
good-to-excellent aesthetic outcomes $=($ excellent cases + good cases)/total number of cases ${ }^{\star} 100 \%$.

Recurrence and mortality rate at one and three years postoperatively: A one- and three-year follow-up was conducted in an out-patient clinic to collect recurrence and mortality rate (Wunderle et al., 2018). The recurrence was observed in molybdenum target X-ray and ultrasound examinations, and telephone survey was made to obtain relevant information from the patients with incomplete follow-up or their families.

Postoperative QoL at one and three years postoperatively: A one- and three-year follow-up was conducted in an out-patient clinic to understand postoperative QoL, which was assessed using the quality of life questionnaire-core 30 (QLQ-C30) and quality of life questionnaire breast cancer module 23 (QLQBR23) developed by the European Organization for Research and Treatment of Cancer (EORTC) (Kontodimopoulos et al., 2011). Main contents of the questionnaires included emotional functioning, social functioning, body image, sexual function and global QoL, with higher scores indicating better QoL.

\subsection{Statistical analysis}

Data analyses were performed with the SPSS 24.0 software. Chi-square test ( $\chi 2$ test) was adopted for the comparison of enumeration data expressed as the case/percentage $(n / \%)$. The measurement data with the normal distribution were expressed as mean \pm standard deviation $(\bar{x} \pm \mathrm{sd})$. Independent $\mathrm{t}$-test was used for the comparison between the two groups, and paired samples t-test was applied for the comparison within the same group. A significant level of $\alpha=0.05$ was adopted. $\mathrm{P}<0.05$ was considered statistically different.

\section{Results}

\subsection{Baseline information}

In the MRM group, 5 of 123 patients dropped out one year after surgery and 18 of 123 patients dropped out three years after surgery, therefore, only 100 patients were included. In the BCS group, 6 of 136 patients dropped out one year after surgery and 30 of 136 patients dropped out three years after surgery, hence, only 100 patients were enrolled. There was no significant difference in age, menopause status and other general data, suggesting that the two groups were comparable $(\mathrm{P}>0.05)$. See Table 1 .

\subsection{Comparison of perioperative outcome measures}

Patients had significantly shorter operation time and hospital stay, smaller incisions, and less intraoperative blood loss in the $\mathrm{BCS}$ group than in the MRM group (all $\mathrm{P}<0.0001$ ). See Table 2.

\subsection{Comparison of complication rates}

Patients in both groups presented with subcutaneous effusion, subcutaneous hemorrhage, infection, and upper limb edema, and no skin flap necrosis was found in the BCS group while one flap necrosis was found in the MRM group. The total

Table 1. Baseline information.

\begin{tabular}{|c|c|c|c|c|}
\hline Items & MRM Group $(n=100)$ & BCS Group $(n=100)$ & $t / \chi^{2}$ & $\mathrm{P}$ \\
\hline Age (year) & $38.2 \pm 8.6$ & $39.3 \pm 9.1$ & 0.879 & 0.381 \\
\hline Menopause (n) & $45(45.0)$ & $38(38.0)$ & 0.149 & 0.670 \\
\hline Onset time (month) & $10.5 \pm 3.2$ & $9.7 \pm 3.6$ & 1.661 & 0.098 \\
\hline Tumor size $(\mathrm{cm})$ & $1.2 \pm 0.9$ & $1.3 \pm 0.7$ & 0.877 & 0.382 \\
\hline \multicolumn{5}{|c|}{ Axillary lymph node metastasis (n) } \\
\hline Yes & $22(22.0)$ & $27(27.0)$ & 0.676 & 0.411 \\
\hline No & $78(78.0)$ & $73(73.0)$ & & \\
\hline \multicolumn{5}{|l|}{ Lesion site } \\
\hline UOQ & $57(57.0)$ & $62(62.0)$ & 0.447 & 0.682 \\
\hline LOQ & $10(10.0)$ & $7(7.0)$ & & \\
\hline UIQ & $22(22.0)$ & $18(18.00)$ & & \\
\hline LIQ & $11(11.0)$ & $13(130)$ & & \\
\hline \multicolumn{5}{|l|}{ TNM stage } \\
\hline Stage I & $68(68.0)$ & $62(62.0)$ & 0.791 & 0.374 \\
\hline Stage II & $32(32.0)$ & $38(38.0)$ & & \\
\hline \multicolumn{5}{|l|}{ Pathological type (n) } \\
\hline Invasive ductal carcinoma & $75(75.0)$ & $70(70.0)$ & 0.125 & 0.771 \\
\hline Invasive lobular carcinoma & $16(16.0)$ & $21(21.0)$ & & \\
\hline Other types & $9(9.0)$ & $9(9.0)$ & & \\
\hline \multicolumn{5}{|l|}{ Immunohistochemistry } \\
\hline ER $(+)$ & 62 & 55 & 1.009 & 0.315 \\
\hline PR (+) & 52 & 56 & 0.322 & 0.570 \\
\hline HER-2 (+++) & 8 & 6 & 0.307 & 0.579 \\
\hline
\end{tabular}

Note: MRM = modified radical mastectomy; BCS = breast-conserving surgery; UOQ = Upper outer quadrant; LOQ = Lower outer quadrant; UIQ = Upper inner quadrant; LIQ = Lower inner quadrant; TNM, tumor-node-metastasis; $t$, statistical value of $t$-test; $\chi^{2}$, Chi square value; $P$, statistical difference. 
complication rate in the BCS group was significantly lower than that in the MRM group (6.0\% vs $16.0 \%, \mathrm{P}=0.024)$. See Table 3.

\subsection{Comparison of aesthetic outcomes}

The patients of the MRM group removed the breast though pectoralis major and minor muscles were preserved, thus aesthetic outcome was poor. The excellent and good rates in the BCS Group were much higher than those in the MRM Group (92.0\% vs $0.0 \%, \mathrm{P}=0.0004)$. See Table 4 .

\subsection{Comparison of prognosis at one and three years postoperatively}

No significant differences were found in local recurrence rate, distant metastasis rate and mortality rate at one and three years postoperatively. $(\mathrm{P}>0.05)$. See Table 5 .

\subsection{Comparison of postoperative QoL at one and three years postoperatively}

At one and three years postoperatively, the scores of emotional functioning, body image, sexual functioning and global QoL in the BCS group were significantly higher than those in the MRM group $(\mathrm{P}<0.0001)$. No significant difference was found in the score of social functioning between the two groups $(\mathrm{P}>0.05)$. Besides, the scores of emotional functioning, social functioning, body image, sexual functioning and global QoL at three years postoperatively were significantly higher than those at one year postoperatively $(\mathrm{P}<0.05)$. See Figure 1.

\section{Discussion}

Our study demonstrates that BCS has better perioperative outcomes and lower complication rates compared with MRM.

Table 2. Comparison of perioperative outcome measures.

\begin{tabular}{lcccc}
\hline \multicolumn{1}{c}{ Items } & MRM Group $(\mathrm{n}=100)$ & BCS Group $(\mathrm{n}=100)$ & $\mathrm{t}$ & $\mathrm{P}$ \\
\hline Operation time (min) & $110.4 \pm 15.0$ & $67.5 \pm 11.8$ & 22.478 & $<0.0001$ \\
Incision length (cm) & $11.8 \pm 1.1$ & $5.1 \pm 0.8$ & 49.259 & $<0.0001$ \\
Intraoperative blood loss (mL) & $81.7 \pm 11.2$ & $49.4 \pm 8.7$ & 22.775 & $<0.0001$ \\
Hospital stay (day) & $14.6 \pm 2.4$ & $11.5 \pm 1.9$ & 10.127 & $<0.0001$ \\
\hline
\end{tabular}

Note: $\mathrm{MRM}=$ modified radical mastectomy; $\mathrm{BCS}$ = breast-conserving surgery.

Table 3. Comparison of complication rates.

\begin{tabular}{lcccccc}
\hline \multicolumn{1}{c}{ Group } & $\begin{array}{c}\text { Subcutaneous } \\
\text { effusion }\end{array}$ & $\begin{array}{c}\text { Subcutaneous } \\
\text { hemorrhage }\end{array}$ & Skin flap necrosis & Infection & $\begin{array}{c}\text { Upper limb edema } \\
\text { Total complication } \\
\text { rate }\end{array}$ \\
\hline MRM Group (n=100) & 6 & 3 & 1 & 3 & 2 & 3 \\
BCS Group (n=100) & 2 & 1 & 0 & & $16.0 \%$ & $6.0 \%$ \\
$\chi^{2}$ & & & & 5.107 & 0.024 \\
P & & & & & \\
\hline
\end{tabular}

Note: $\mathrm{MRM}=$ modified radical mastectomy; $\mathrm{BCS}$ = breast-conserving surgery.

Table 4. Comparison of aesthetic outcomes.

\begin{tabular}{lccccc}
\hline \multicolumn{1}{c}{ Group } & Excellent & Good & Fair & Poor & Excellent and good rate \\
\hline MRM Group (n=100) & 0 & 0 & 0 & 100 & $0.0 \%$ \\
BSC Group (n=100) & 84 & 8 & 6 & 2 & $92.0 \%$ \\
$\chi^{2}$ & & & & 170.4 \\
P & & & & $<0.0001$ \\
\hline
\end{tabular}

Note: $\mathrm{MRM}=$ modified radical mastectomy; $\mathrm{BCS}$ = breast-conserving surgery.

Table 5. Comparison of prognosis at one and three years postoperatively.

\begin{tabular}{|c|c|c|c|c|c|c|}
\hline \multirow[b]{2}{*}{ Group } & \multicolumn{2}{|c|}{ Local recurrence rate } & \multicolumn{2}{|c|}{ Distant metastasis rate } & \multicolumn{2}{|c|}{ Mortality rate } \\
\hline & $\begin{array}{c}1 \text { year } \\
\text { postoperatively }\end{array}$ & $\begin{array}{c}3 \text { year } \\
\text { postoperatively }\end{array}$ & $\begin{array}{c}1 \text { year } \\
\text { postoperatively }\end{array}$ & $\begin{array}{c}3 \text { year } \\
\text { postoperatively }\end{array}$ & $\begin{array}{c}1 \text { year } \\
\text { postoperatively }\end{array}$ & $\begin{array}{c}3 \text { year } \\
\text { postoperatively }\end{array}$ \\
\hline $\begin{array}{c}\text { MRM } \\
\text { Group } \\
(n=100)\end{array}$ & $1(1.0)$ & $2(2.0)$ & $1(1.0)$ & $3(3.0)$ & $0(0.0)$ & $2(2.0)$ \\
\hline $\begin{array}{c}\text { BCS } \\
\text { Group } \\
(\mathrm{n}=100)\end{array}$ & $1(1.0)$ & $4(4.0)$ & $0(0.0)$ & $4(4.0)$ & $0(0.0)$ & $3(3.0)$ \\
\hline$\chi^{2}$ & 0.505 & 0.172 & & 0.000 & & 0.000 \\
\hline $\mathbf{P}$ & 1.477 & 0.678 & 0.500 & 1.000 & 1.000 & 1.000 \\
\hline
\end{tabular}

Note: $\mathrm{MRM}=$ modified radical mastectomy; $\mathrm{BCS}=$ breast-conserving surgery. 
A

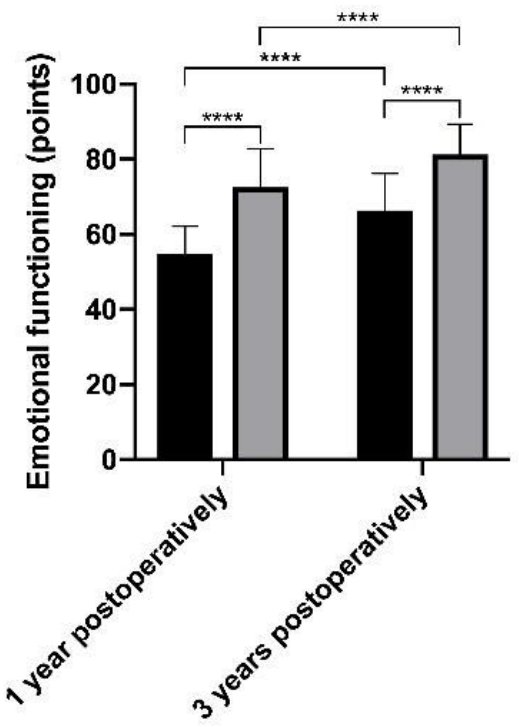

D

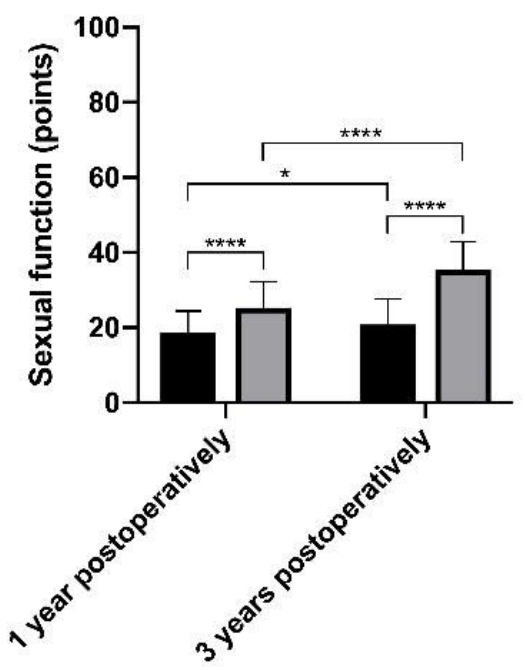

B

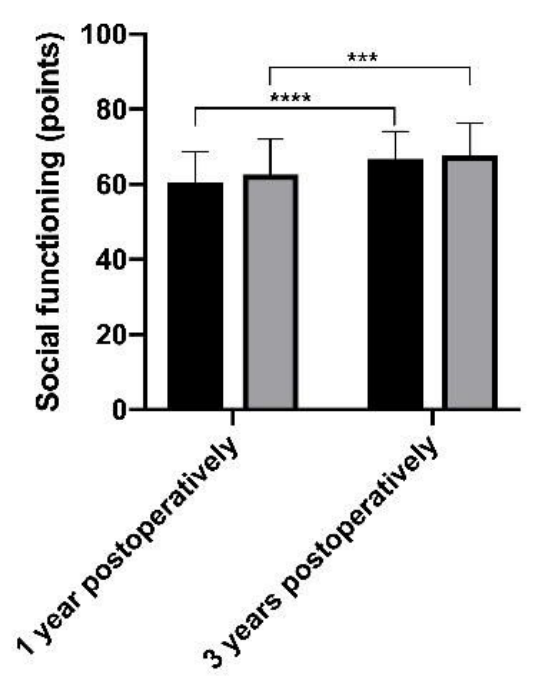

E

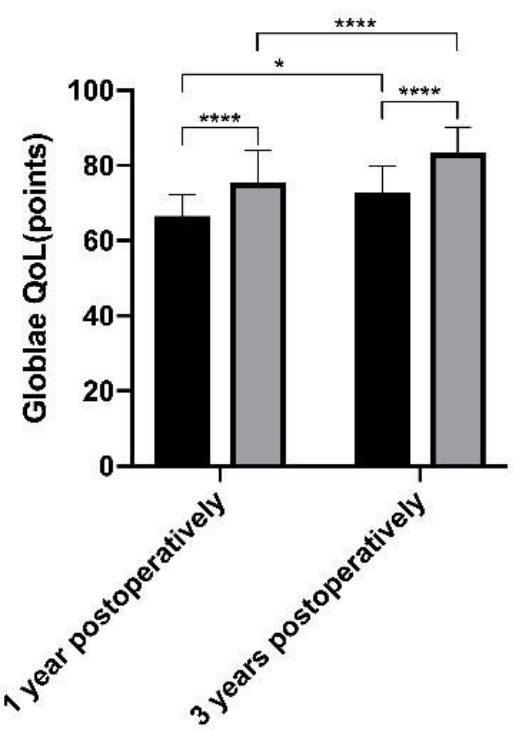

C
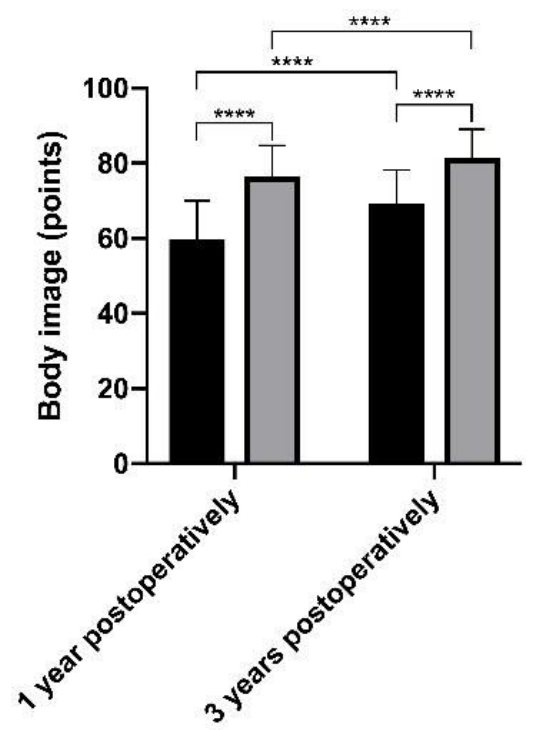

MRM group $(\mathrm{n}=100)$

BCS group $(n=100)$

Figure 1. Comparison of postoperative QoL at one and three years postoperatively. (A) Emotional functioning: Compared with the MRM group, ${ }^{* * *} \mathrm{P}<0.0001$; (B) Social functioning: Compared with the MRM group, ${ }^{* * *} \mathrm{P}<0.001,{ }^{* * *} \mathrm{P}<0.0001$; (C) Body image: Compared with the MRM group, ${ }^{* * * *} \mathrm{P}<0.0001$; (D) Sexual functioning: Compared with the MRM group, ${ }^{\star} \mathrm{P}<0.05,{ }^{* * *} \mathrm{P}<0.0001$; (E) Global QoL: Compared with the MRM group, ${ }^{\star} \mathrm{P}<0.05,{ }^{* * * *} \mathrm{P}<0.0001$. Note: $\mathrm{QoL}=$ quality of life; $\mathrm{MRM}=$ modified radical mastectomy; $\mathrm{BCS}=$ breast-conserving surgery.

Wang et al. (2019a) identified that a shorter operation time of BCS contributed to less trauma, and better recovery and perioperative outcomes. Guo et al. (2017) reported that breast removal in patients undergoing MRM had a destructive effect on breasts, and thus predisposed to complications such as subcutaneous effusion, subcutaneous hemorrhage, infection, and upper limb edema after surgery. In this study, patients treated with BCS had significantly shorter operation time, smaller incisions and less blood loss than those treated with MRM, which promoted more rapid discharge. Additionally, the complication rates were significantly higher in the MRM group than in the BCS group due to the more serious destruction of MRM to the surrounding tissues of mammary glands. Main reasons for better perioperative outcomes and lower postoperative complication rates of BCS were: only breast tissue invaded by the single tumors was removed in BCS, which was less invasive than MRM in which the breast was completely removed; free flaps were used on the affected side, which caused damage to the superficial fascia as well as the tissues around the pectoralis major and minor muscles (Guo et al., 2018; Mohamed et al., 2019).

Our study reveals that BCS confers a better postoperative QoL than MRM. A 3-year follow-up study reported by Rosenberg et al. 
(2019) found that the QoL of patients treated with BCS was only slightly affected by physical trauma, anxiety, etc., and their daily life remained normal; the QoL of patients treated with MRM was severely affected in terms of the sexual life, self-emotion, etc., which caused great psychological pressure. Since patients undergoing MRM might use breast pads to maintain their secondary sexual characteristics, the social functioning was not greatly affected. Similarly, Kaur et al. (2018) assessed aesthetic outcomes and showed that the QoL of patients with early BC was mainly related to whether the breast was retained or the shape of breast was considered satisfactory. In line with the two studies above, our study showed a better postoperative QoL in patients undergoing BCS than in patients undergoing MRM. Furthermore, we improved the assessment of QoL at one and three years after surgery in terms of emotional functioning, social functioning, body image, sexual functioning, and global QoL. Although pectoralis major and minor muscles were preserved in the MRM group, postoperative aesthetic outcome and were still evaluated as poor by Harris's 4-staged subjective evaluation method because the breast was completely removed (Wang et al., $2019 b$ ). The rate of good-to-excellent aesthetic outcomes in the BCS group was up to $92.0 \%$, suggesting that BCS has little effect on the shape and texture of the affected breasts. Unlike previous studies, we found that the indicators of QoL at three years after surgery were significantly improved compared with those at one year after surgery, which may indicate that postoperative patients with $\mathrm{BC}$ gradually adapt themselves to the change.

Prognosis is the primary concern in clinical practice. In this study, we confirm that BCS offers a good prognosis equivalent to MRM. There was no significant difference in the local recurrence, distant metastasis and mortality rate at one and three years after surgery between the two groups. A metaanalysis for the prognosis of BCS and MRM showed that there was no significant difference in the prognosis (Zehra et al., 2020). Notably, the postoperative recurrence rate of early BC was significantly reduced with the development of radiotherapy, chemotherapy and endocrine therapy (Kontodimopoulos et al., 2011). De Lorenzi et al. reported in 2000 that the recurrence rate at three years after BCS was about $15.0 \%$, which was significantly higher than that in our study (4.0\%) (De Lorenzi et al., 2016). This is mainly due to the improvement in adjuvant therapy, surgical resection, LND, and early diagnosis (van Maaren et al., 2016; Jagsi et al., 2019).

Several limitations still remain in this study though we have achieved certain positive results. This was single-centered study for a better follow-up effect. QoL was mainly assessed by questionnaire survey after surgery instead of before and after surgery. Moreover, the scale reliability and validity were not analyzed in this study though they were verified in previous studies. This was a three-year follow-up study, and longer followup was not performed. Therefore, we will use larger sample sizes of multi-center trials with long-term follow-up to get a more precise conclusion in the future.

In summary, BCS offers a good prognosis equivalent to MRM, and leads to less trauma, and better aesthetic outcome and QoL than MRM, which is more worthy of being promoted clinically in treating early BC.

\section{Abbreviations}

QoL: quality of life. BCS: breast-conserving surgery. MRM: modified radical mastectomy. BC: Breast cancer. LND: lymph node dissection. ER: estrogen receptor. PR: progesterone receptor. HER-2: human epidermal growth factor receptor-2. QLQ-C30: quality of life questionnaire-core 30. QLQ-BR23: quality of life questionnaire breast cancer module 23. EORTC: European Organization for Research and Treatment of Cancer.

\section{Conflict of interest}

The authors declare that they have no competing interest.

\section{Availability of data and material}

The raw data for this study are available upon reasonable request to the corresponding author.

\section{Author contributions}

Heng Liu was dedicated to the integrity of the entire study, study concepts, study design, definition of intellectual content, clinical studies, data analysis, statistical analysis, manuscript preparation and manuscript editing; Chengyu Luo was involved in the literature research, data acquisition and manuscript review. All authors have read and approved this article.

\section{References}

Balthazar, C. F., de Moura, N. A., Romualdo, G. R., Rocha, R. S., Pimentel, T. C., Esmerino, E. A., Freitas, M. Q., Santillo, A., Silva, M. C., Barbisan, L. F., Cruz, A. G., \& Albenzio, M. (2021). Synbiotic sheep milk ice cream reduces chemically induced mouse colon carcinogenesis. Journal of Dairy Science, 104(7), 7406-7414. http:// dx.doi.org/10.3168/jds.2020-19979. PMid:33934866.

Benjamin, M. A., Sinnott, C., Bawa, S., Kaufman, D. I., Guarino, K., \& Addona, T. (2019). Re-excision rate after partial mastectomy in oncoplastic breast-conserving surgery: a single-institutional experience and review of the literature. Annals of Plastic Surgery, 82(4S, Suppl. 3), S170-s172. http://dx.doi.org/10.1097/SAP.0000000000001874. PMid:30855383.

Bland, K. I., Chang, H. R., \& Copeland, E. M. III. (2018) Modified radical mastectomy and simple mastectomy. In K. I. Bland, E. M. Copeland III, V. S. Klimberg \& W. J. Gradishar (Eds.), The breast: comprehensive management of benign and malignant diseaseshe breast (pp. 443-461). Philadelphia: Elsevier. http://dx.doi.org/10.1016/ B978-0-323-35955-9.00031-3.

Cardoso, F., Kyriakides, S., Ohno, S., Penault-Llorca, F., Poortmans, P., Rubio, I. T., Zackrisson, S., \& Senkus, E. (2019). Early breast cancer: ESMO Clinical Practice Guidelines for diagnosis, treatment and follow-up. Annals of Oncology, 30(10), 1674. http://dx.doi. org/10.1093/annonc/mdz189. PMid:31236598.

Clough, K. B., van la Parra, R. F. D., Thygesen, H. H., Levy, E., Russ, E., Halabi, N. M., Sarfati, I., \& Nos, C. (2018). Long-term results after oncoplastic surgery for breast cancer: a 10-year follow-up. Annals of Surgery, 268(1), 165-171. http://dx.doi.org/10.1097/ SLA.0000000000002255. PMid:28448389.

De Lorenzi, F., Hubner, G., Rotmensz, N., Bagnardi, V., Loschi, P., Maisonneuve, P., Venturino, M., Orecchia, R., Galimberti, V., Veronesi, P., \& Rietjens, M. (2016). Oncological results of oncoplastic breast-conserving surgery: Long term follow-up of a large series at 
a single institution: a matched-cohort analysis. European Journal of Surgical Oncology, 42(1), 71-77. http://dx.doi.org/10.1016/j. ejso.2015.08.160. PMid:26382101.

Deepa, K. V., Gadgil, A., Lofgren, J., Mehare, S., Bhandarkar, P., \& Roy, N. (2020). Is quality of life after mastectomy comparable to that after breast conservation surgery? A 5-year follow up study from Mumbai, India. Quality of Life Research: An International Journal of Quality of Life Aspects of Treatment, Care and Rehabilitation, 29(3), 683-692. http://dx.doi.org/10.1007/s11136-019-02351-1. PMid:31712944.

Deng, M., Chen, H. H., Zhu, X., Luo, M., Zhang, K., Xu, C. J., Hu, K. M., Cheng, P., Zhou, J. J., Zheng, S., \& Chen, Y. D. (2019). Prevalence and clinical outcomes of germline mutations in BRCA1/2 and PALB2 genes in 2769 unselected breast cancer patients in China. International Journal of Cancer, 145(6), 1517-1528. http://dx.doi. org/10.1002/ijc.32184. PMid:30720863.

DeSantis, C. E., Ma, J., Goding Sauer, A., Newman, L. A., \& Jemal, A. (2017). Breast cancer statistics, 2017, racial disparity in mortality by state. CA: a Cancer Journal for Clinicians, 67(6), 439-448. http:// dx.doi.org/10.3322/caac.21412. PMid:28972651.

Ein Ali Afjeh, M., Pourahmad, R., Akbari-Adergani, B., \& Azin, M. (2020). Characteristics of glucose oxidase immobilized on magnetic chitosan nanoparticles. Food Science and Technology, 40(1), 68-75. http://dx.doi.org/10.1590/fst.32618.

Fan, D. W., Li, X. H., Yao, C. Y., Zhang, C., \& Yao, T. (2017). Clinical efficacy of patients with breast cancer treated with breast-conserving therapy and modified radical mastectomy in China. International Journal of Surgery, 44(9), 603-606.

Farre, A., \& Rapley, T. (2017). The new old (and old new) medical model: four decades navigating the biomedical and psychosocial understandings of health and illness. Healthcare, 5(4), 88. http:// dx.doi.org/10.3390/healthcare5040088. PMid:29156540.

Fulton, C., Davis, L. E., Mahar, A. L., Bubis, L. D., Moody, L., Li, Q., Barbera, L., Coburn, N. G., \& Holloway, C. (2019). Patient-reported symptoms in the perioperative period of breast cancer treatment. The Breast, 1, 3.

Grotkamp, S., Cibis, W., Bruggemann, S., Coenen, M. M., Gmünder, H. P., Keller, K., Nüchtern, E., Schwegler, U., Seger, W., Staubli, S., Raison, B. B. V., Weißmann, R., Bahemann, A., Fuchs, H., Rink, M., Schian, M., \& Schmitt, K. (2020). Personal factors of the bio-psychosocial model (WHO): a revised classification by the German Society for Social Medicine and Prevention (DGSMP). Gesundheitswesen, 82(1), 107-116. PMid:31634963.

Guo, W. L., Lu, J. J., \& Huang, J. Q. (2017). Effects of different surgical procedures on clinical outcomes and quality of life in patients with breast cancer. Zhongguo Jiceng Yiyao, 24(4), 578-581.

Guo, Y., Zhang, L., \& Gu, L. (2018). Feasibility of neoadjuvant chemotherapy combined with breast conserving surgery for breast cancer. Tumor, 38, 242-249.

Hossen, M. T., Ferdaus, M. J., Hasan, M. M., Lina, N. N., Das, A. K., Barman, S. K., Paul, D. K., \& Roy, R. K. (2021). Food safety knowledge, attitudes and practices of street food vendors in Jashore region, Bangladesh. Food Sci. Technol, 41(Suppl. 1), 226-239. http:// dx.doi.org/10.1590/fst.13320.

Jagsi, R., Griffith, K., Harris, E., Wright, J. L., Recht, A., Taghian, A. G., Lee, L., Moran, M. S., Thomas, T. O. Jr., Johnstone, C., Rahimi, A. S., Freedman, G. M., Muzaffar, M., Haffty, B. G. Jr., Horst, K. C., Powell, S. N., Sharp, J., Sabel, M. S., Schott, A. F., \& El-Tamer, M. (2019). Planned Interim Analysis Results from a Prospective Multicenter Single-Arm Cohort Study of Patients Receiving Endocrine Therapy but Not Radiotherapy after Breast-Conserving Surgery for EarlyStage Breast Cancer with Favorable Biologic Features. International
Journal of Radiation Oncology, Biology, Physics, 105(1), S7-S8. http:// dx.doi.org/10.1016/j.ijrobp.2019.06.392.

Kaur, N., Gupta, A., Sharma, A. K., \& Jain, A. (2018). Survivorship issues as determinants of quality of life after breast cancer treatment: report from a limited resource setting. The Breast, 41, 120-126. http:// dx.doi.org/10.1016/j.breast.2018.07.003. PMid:30029054.

Kontodimopoulos, N., Ntinoulis, K., \& Niakas, D. (2011). Validity of the Greek EORTC QLQ-C30 and QLQ-BR23 for measuring healthrelated quality of life in breast cancer patients. European Journal of Cancer Care, 20(3), 354-361. http://dx.doi.org/10.1111/j.13652354.2009.01170.x. PMid:20345453.

Lee, A., Mavaddat, N., Wilcox, A. N., Cunningham, A. P., Carver, T., Hartley, S., Babb de Villiers, C., Izquierdo, A., Simard, J., Schmidt, M. K., Walter, F. M., Chatterjee, N., Garcia-Closas, M., Tischkowitz, M., Pharoah, P., Easton, D. F., \& Antoniou, A. C. (2019). BOADICEA: a comprehensive breast cancer risk prediction model incorporating genetic and nongenetic risk factors. Genetics in Medicine, 21(8), 17081718. http://dx.doi.org/10.1038/s41436-018-0406-9. PMid:30643217.

Mavaddat, N., Michailidou, K., Dennis, J., Lush, M., Fachal, L., Lee, A., Tyrer, J. P., Chen, T. H., Wang, Q., Bolla, M. K., Yang, X., Adank, M. A., Ahearn, T., Aittomäki, K., Allen, J., Andrulis, I. L., AntonCulver, H., Antonenkova, N. N., Arndt, V., Aronson, K. J., Auer, P. L., Auvinen, P., Barrdahl, M., Beane Freeman, L. E., Beckmann, M. W., Behrens, S., Benitez, J., Bermisheva, M., Bernstein, L., Blomqvist, C., Bogdanova, N. V., Bojesen, S. E., Bonanni, B., Børresen-Dale, A. L., Brauch, H., Bremer, M., Brenner, H., Brentnall, A., Brock, I. W., Brooks-Wilson, A., Brucker, S. Y., Brüning, T., Burwinkel, B., Campa, D., Carter, B. D., Castelao, J. E., Chanock, S. J., Chlebowski, R., Christiansen, H., Clarke, C. L., Collée, J. M., Cordina-Duverger, E., Cornelissen, S., Couch, F. J., Cox, A., Cross, S. S., Czene, K., Daly, M. B., Devilee, P., Dörk, T., Dos-Santos-Silva, I., Dumont, M., Durcan, L., Dwek, M., Eccles, D. M., Ekici, A. B., Eliassen, A. H., Ellberg, C., Engel, C., Eriksson, M., Evans, D. G., Fasching, P. A., Figueroa, J., Fletcher, O., Flyger, H., Försti, A., Fritschi, L., Gabrielson, M., Gago-Dominguez, M., Gapstur, S. M., García-Sáenz, J. A., Gaudet, M. M., Georgoulias, V., Giles, G. G., Gilyazova, I. R., Glendon, G., Goldberg, M. S., Goldgar, D. E., González-Neira, A., Grenaker Alnæs, G. I., Grip, M., Gronwald, J., Grundy, A., Guénel, P., Haeberle, L., Hahnen, E., Haiman, C. A., Håkansson, N., Hamann, U., Hankinson, S. E., Harkness, E. F., Hart, S. N., He, W., Hein, A., Heyworth, J., Hillemanns, P., Hollestelle, A., Hooning, M. J., Hoover, R. N., Hopper, J. L., Howell, A., Huang, G., Humphreys, K., Hunter, D. J., Jakimovska, M., Jakubowska, A., Janni, W., John, E. M., Johnson, N., Jones, M. E., Jukkola-Vuorinen, A., Jung, A., Kaaks, R., Kaczmarek, K., Kataja, V., Keeman, R., Kerin, M. J., Khusnutdinova, E., Kiiski, J. I., Knight, J. A., Ko, Y. D., Kosma, V. M., Koutros, S., Kristensen, V. N., Krüger, U., Kühl, T., Lambrechts, D., Le Marchand, L., Lee, E., Lejbkowicz, F., Lilyquist, J., Lindblom, A., Lindström, S., Lissowska, J., Lo, W. Y., Loibl, S., Long, J., Lubiński, J., Lux, M. P., MacInnis, R. J., Maishman, T., Makalic, E., Maleva Kostovska, I., Mannermaa, A., Manoukian, S., Margolin, S., Martens, J. W. M., Martinez, M. E., Mavroudis, D., McLean, C., Meindl, A., Menon, U., Middha, P., Miller, N., Moreno, F., Mulligan, A. M., Mulot, C., Muñoz-Garzon, V. M., Neuhausen, S. L., Nevanlinna, H., Neven, P., Newman, W. G., Nielsen, S. F., Nordestgaard, B. G., Norman, A., Offit, K., Olson, J. E., Olsson, H., Orr, N., Pankratz, V. S., ParkSimon, T. W., Perez, J. I. A., Pérez-Barrios, C., Peterlongo, P., Peto, J., Pinchev, M., Plaseska-Karanfilska, D., Polley, E. C., Prentice, R., Presneau, N., Prokofyeva, D., Purrington, K., Pylkäs, K., Rack, B., Radice, P., Rau-Murthy, R., Rennert, G., Rennert, H. S., Rhenius, V., Robson, M., Romero, A., Ruddy, K. J., Ruebner, M., Saloustros, E., Sandler, D. P., Sawyer, E. J., Schmidt, D. F., Schmutzler, R. K., Schneeweiss, A., Schoemaker, M. J., Schumacher, F., Schürmann, 
P., Schwentner, L., Scott, C., Scott, R. J., Seynaeve, C., Shah, M., Sherman, M. E., Shrubsole, M. J., Shu, X. O., Slager, S., Smeets, A., Sohn, C., Soucy, P., Southey, M. C., Spinelli, J. J., Stegmaier, C., Stone, J., Swerdlow, A. J., Tamimi, R. M., Tapper, W. J., Taylor, J. A., Terry, M. B., Thöne, K., Tollenaar, R. A. E. M., Tomlinson, I., Truong, T., Tzardi, M., Ulmer, H. U., Untch, M., Vachon, C. M., van Veen, E. M., Vijai, J., Weinberg, C. R., Wendt, C., Whittemore, A. S., Wildiers, H., Willett, W., Winqvist, R., Wolk, A., Yang, X. R., Yannoukakos, D., Zhang, Y., Zheng, W., Ziogas, A., Dunning, A. M., Thompson, D. J., Chenevix-Trench, G., Chang-Claude, J., Schmidt, M. K., Hall, P., Milne, R. L., Pharoah, P. D. P., Antoniou, A. C., Chatterjee, N., Kraft, P., García-Closas, M., Simard, J., \& Easton, D. F. (2019). Polygenic risk scores for prediction of breast cancer and breast cancer subtypes. American Journal of Human Genetics, 104(1), 21-34. http://dx.doi. org/10.1016/j.ajhg.2018.11.002. PMid:30554720.

Mohamed, F., Ahmed, S. A., \& Mohamed, A. E.-M. (2019). Breastconserving therapy versus modified radical mastectomy in the early breast cancer management: oncological outcome and quality of life. The Medical Journal of Cairo University, 87, 1639-1647. http://dx.doi. org/10.21608/mjcu.2019.53898.

Morra, A., Jung, A. Y., Behrens, S., Yang, R., Eliassen, H., Holmes, M., García-Closas, M., Schmidt, M. K., \& Chang-Claude, J. (2019). Breast cancer risk factors and survival by tumor subtypes: a pooled analysis from the Breast Cancer Association Consortium studies. Cancer Research, 79(13, Suppl.), 3286.

Moyer, A. (1997). Psychosocial outcomes of breast-conserving surgery versus mastectomy: a meta-analytic review. Health Psychology, 16(3), 284-298. http://dx.doi.org/10.1037/0278-6133.16.3.284. PMid:9152708.

Rosenberg, S. M., O’Neill, A., Sepucha, K., Miller, K. D., Dang, C. T., Northfelt, D. W., Sledge, G. W., Schneider, B.P., \& Partridge, A. H. (2019). Abstract GS6-05: the impact of breast cancer surgery on quality of life: long term results from E5103. Cancer Research, 79(4, Suppl.), GS6-05.

Sajikumar, N., Syamsunder, S., \& Pinheiro, C. (2019). Proportions and reasons for breast conservation surgery and modified radical mastectomy in early breast carcinoma. International Surgery Journal, 6(7), 2405-2410. http://dx.doi.org/10.18203/2349-2902.isj20192964.

Si, Y., Yuan, P., Hu, N., Wang, X., Ju, J., Wang, J., Ma, F., Luo, Y., Zhang, P., Li, Q., \& Xu, B. (2020). Primary tumor surgery for patients with de novo stage IV breast cancer can decrease local symptoms and improve quality of life. Annals of Surgical Oncology, 27(4), 1025-1033. http://dx.doi.org/10.1245/s10434-019-08092-2. PMid:31970572.

Strnad, V., Ott, O. J., Hildebrandt, G., Kauer-Dorner, D., Knauerhase, H., Major, T., Lyczek, J., Guinot, J. L., Dunst, J., Miguelez, C. G., Slampa, P., Allgäuer, M., Lössl, K., Polat, B., Kovács, G., Fischedick, A.-R., Wendt, T. G., Fietkau, R., Hindemith, M., Resch, A., Kulik, A., Arribas, L., Niehoff, P., Guedea, F., Schlamann, A., Pötter, R., Gall, C., Malzer, M., Uter, W., \& Polgár, C. (2016). 5-year results of accelerated partial breast irradiation using sole interstitial multicatheter brachytherapy versus whole-breast irradiation with boost after breast-conserving surgery for low-risk invasive and in-situ carcinoma of the female breast: a randomised, phase 3, non-inferiority trial. Lancet, 387(10015), 229-238. http://dx.doi. org/10.1016/S0140-6736(15)00471-7. PMid:26494415.
Thakur, S. B., Horvat, J. V., Hancu, I., Sutton, O. M., Bernard-Davila, B., Weber, M., Oh, J. H., Marino, M. A., Avendano, D., Leithner, D., Brennan, S., Giri, D., Manderski, E., Morris, E. A., \& Pinker, K. (2019). Quantitative in vivo proton MR spectroscopic assessment of lipid metabolism: value for breast cancer diagnosis and prognosis. Journal of Magnetic Resonance Imaging, 50(1), 239-249. http://dx.doi. org/10.1002/jmri.26622. PMid:30605266.

van Bommel, A., \& van Dalen, T. (2019). ASO author reflections: breast contour-preserving procedures as a means to address the esthetic outcome of breast cancer treatment. Annals of Surgical Oncology, 26(Suppl. 3), 721-722. http://dx.doi.org/10.1245/s10434-019-077705. PMid:31485822.

van Maaren, M. C., Munck, L., Bock, G. H., Jobsen, J. J., van Dalen, T., Linn, S. C., Poortmans, P., Strobbe, L. J. A., \& Siesling, S. (2016). 10 year survival after breast-conserving surgery plus radiotherapy compared with mastectomy in early breast cancer in the Netherlands: a population-based study. The Lancet. Oncology, 17(8), 1158-1170. http://dx.doi.org/10.1016/S1470-2045(16)30067-5. PMid:27344114.

von Minckwitz, G., Procter, M., Azambuja, E., Zardavas, D., Benyunes, M., Viale, G., Suter, T., Arahmani, A., Rouchet, N., Clark, E., Knott, A., Lang, I., Levy, C., Yardley, D. A., Bines, J., Gelber, R. D., Piccart, M., \& Baselga, J. (2017). Adjuvant pertuzumab and trastuzumab in early HER2-positive breast cancer. The New England Journal of Medicine, 377(2), 122-131. http://dx.doi.org/10.1056/NEJMoa1703643. PMid:28581356.

Wang, H. Y., Li, Z., \& Sun, S. F. (2019a). Effect of modified radical mastectomy and breast conserving surgery on early breast cancer patients. China Foreign Medical Treatment, 38(2), 68-70.

Wang, S. E., Sun, Y. D., Zhao, S. J., Wei, F., \& Yang, G. (2019b). Breast conserving surgery (BCS) with adjuvant radiation therapy showed improved prognosis compared with mastectomy for early staged triple negative breast cancer patients. Mathematical Biosciences and Engineering, 17(1), 92-104. http://dx.doi.org/10.3934/mbe.2020005. PMid:31731341.

Wunderle, M., Gass, P., Haberle, L., Flesch, V. M., Rauh, C., Bani, M. R., Hack, C. C., Schrauder, M. G., Jud, S. M., Emons, J., Erber, R., Ekici, A. B., Hoyer, J., Vasileiou, G., Kraus, C., Reis, A., Hartmann, A., Lux, M. P., Beckmann, M. W., Fasching, P. A., \& Hein, A. (2018). BRCA mutations and their influence on pathological complete response and prognosis in a clinical cohort of neoadjuvantly treated breast cancer patients. Breast Cancer Research and Treatment, 171(1), 8594. http://dx.doi.org/10.1007/s10549-018-4797-8. PMid:29725888.

Zehra, S., Doyle, F., Barry, M., Walsh, S., \& Kell, M. R. (2020). Healthrelated quality of life following breast reconstruction compared to total mastectomy and breast-conserving surgery among breast cancer survivors: a systematic review and meta-analysis. Breast Cancer, 27(4), 534. http://dx.doi.org/10.1007/s12282-020-01076-1. PMid:32162181.

Zhang, L., Jiang, M., Zhou, Y., Du, X. B., Yao, W. X., Yan, X., Jiang, Y., \& Zou, L. Q. (2012). Survey on breast cancer patients in China toward breast-conserving surgery. Psycho-Oncology, 21(5), 488-495. http:// dx.doi.org/10.1002/pon.1922. PMid:21322089. 